\title{
Treatment of leptomeningeal metastases evaluated by interphase cytogenetics.
}

Citation for published version (APA):

van Oostenbrugge, R. J., Hopman, A. H. N., Arends, J. W., Ramaekers, F. C. S., \& Twijnstra, A. (2000). Treatment of leptomeningeal metastases evaluated by interphase cytogenetics. Journal of Clinical Oncology, 18, 2053-8. https://doi.org/10.1200/JCO.2000.18.10.2053

Document status and date:

Published: 01/01/2000

DOI:

10.1200/JCO.2000.18.10.2053

Document Version:

Publisher's PDF, also known as Version of record

\section{Please check the document version of this publication:}

- A submitted manuscript is the version of the article upon submission and before peer-review. There can be important differences between the submitted version and the official published version of record.

People interested in the research are advised to contact the author for the final version of the publication, or visit the DOI to the publisher's website.

- The final author version and the galley proof are versions of the publication after peer review.

- The final published version features the final layout of the paper including the volume, issue and page numbers.

Link to publication

\footnotetext{
General rights rights.

- You may freely distribute the URL identifying the publication in the public portal. please follow below link for the End User Agreement:

www.umlib.nl/taverne-license

Take down policy

If you believe that this document breaches copyright please contact us at:

repository@maastrichtuniversity.nl

providing details and we will investigate your claim.
}

Copyright and moral rights for the publications made accessible in the public portal are retained by the authors and/or other copyright owners and it is a condition of accessing publications that users recognise and abide by the legal requirements associated with these

- Users may download and print one copy of any publication from the public portal for the purpose of private study or research.

- You may not further distribute the material or use it for any profit-making activity or commercial gain

If the publication is distributed under the terms of Article $25 \mathrm{fa}$ of the Dutch Copyright Act, indicated by the "Taverne" license above, 


\title{
Treatment of Leptomeningeal Metastases Evaluated by Interphase Cytogenetics
}

\author{
By R.J. van Oostenbrugge, A.H.N. Hopman, J.W. Arends, F.C.S. Ramaekers, and A. Twijnstra
}

\begin{abstract}
Purpose: Although cytologic examination of CSF is the primary method for the evaluation of response to therapy for leptomeningeal metastases (LMMs), the procedure's sensitivity decreases throughout the course of protracted therapy. We studied whether this response could be monitored more accurately through the detection of numerical chromosomal aberrations by interphase cytogenetics, using fluorescence in situ hybridization (FISH).

Patients and Methods: Seven patients treated for LMMs and with a known numerical aberration for chromosome 1 in their pretreatment CSF were included in this study. Up to 16 consecutive CSF samples were analyzed by means of the fluorescence in situ hybridization (FISH) technique for cells with aberrant chromosome 1 content. The results of routine cytology and FISH analyses were compared and were correlated with each patient's neurologic status.
\end{abstract}

$\mathrm{M}$ ETASTATIC SPREAD to the leptomeninges is estimated to occur in up to $8 \%$ of patients with systemic cancer and is characterized by diffuse and often multifocal infiltration of the leptomeninges. ${ }^{1}$ Current treatment modalities include the administration of chemotherapeutic agents into the subarachnoid space., ${ }^{1,2}$ Evaluation of treatment response is difficult, despite the fact that several methods are currently available. Boogerd et $\mathrm{al}^{3}$ found clinical neurologic status to be a good predictor of the response to therapy; however, neurologic improvement is generally hard to achieve because of irreversible damage of the nervous tissue by the tumor. Tumor response is usually assessed by sequential cytologic examinations of the CSF. ${ }^{2}$ However, this method loses much of its sensitivity throughout the course of protracted therapy, because of a decrease in cell number, cellular changes (such as cell enlargement, cytoplasmic vacuolization, and multinucleation), and the presence of reactive ependymal cells in the CSF. ${ }^{4}$ Furthermore, Shapiro et $\mathrm{al}^{5}$ reported that malignant meningeal infiltration was detected at autopsy in all treated patients, even in patients with apparently normal CSF cytology results before death.

Additional tests, such as immunocytochemistry and biochemical tumor marker assays, are considered to be of no additional value in evaluating the response to therapy in the case of leptomeningeal metastases (LMMs) because of their lack of sensitivity. ${ }^{2}$ The few exceptions are carcinoembryonic antigen tests in the case of LMMs of solid tumors and the soluble form of CD-27 in the CSF of patients with leukemic LMMs, which have proved to be sensitive markers for response to therapy. 6,7
Results: Routine cytology detected malignancies in only 24 of the 76 samples, all of which were classified as chromosomally abnormal by FISH (except for two samples that could not be evaluated). Moreover, FISH demonstrated aneusomic cells in 32 additional samples, which could therefore be classified as malignant. The FISH results correlated better with patient neurologic status in that more malignant cells were detected in the CSF of neurologically deteriorating patients.

Conclusion: Using FISH in addition to performing routine cytologic examination of CSF led to a more accurate evaluation of response to treatment in patients treated for LMMs.

J Clin Oncol 18:2053-2058. (-) 2000 by American Society of Clinical Oncology.

The in situ hybridization technique is based on the targeted detection of numerical or structural chromosomal aberrations in the interphase nucleus by means of specific DNA probes. ${ }^{8}$ The application of this method is therefore generally referred to as interphase cytogenetics. The usefulness of this technique in CSF cytodiagnosis has been demonstrated, showing that only malignant CSF samples contained cells with an increased copy number for chromosome $1 .{ }^{9}$ It has already been demonstrated by flow cytometric studies that DNA aneuploidy is associated with malignancy and that aneuploidy for chromosome 1 is generally a good indicator of DNA aneuploidy. ${ }^{10,11}$ Because other studies have also detected an exclusive increase in the copy number of chromosome 1 in (pre)malignant lesions and no aneusomy for chromosome 1 in normal tissue, it is assumed that cells with an increased copy number truly represent malignant cells. ${ }^{12,13}$ An increase in the copy number of chromosome 1 is usually accompanied by aberrations in other chromosomes. ${ }^{14,15}$

From the Departments of Neurology and Pathology, University Hospital of Maastricht, and Department of Molecular Cell Biology and Genetics, University of Maastricht, Maastricht, the Netherlands.

Submitted September 7, 1999; accepted January 25, 2000.

Supported by a grant from the Dutch Cancer Society, Amsterdam, the Netherlands.

Address reprint requests to R.J. van Oostenbrugge, $M D$, $P h D$, Department of Neurology, University Hospital Maastricht, PO Box 5800, 6202 AZ Maastricht, the Netherlands; email rvoo@ sneu.azm.nl. (C) 2000 by American Society of Clinical Oncology.

0732-183X/00/1810-2053 
Recent studies have shown that interphase cytogenetics are more sensitive than routine cytology in detecting residual tumor cells present in bone marrow and recurrent bladder cancer in bladder irrigation specimens. ${ }^{16-18}$ The aim of the study presented here was to evaluate the diagnostic value of interphase cytogenetics for the assessment of persistent malignancy in the CSF during the treatment of LMMs.

\section{PATIENTS AND METHODS}

Seven patients with LMMs of systemic cancer diagnosed by the cytologic detection of malignant cells in the CSF, and with a known numerical aberration for chromosome 1 detected by fluorescence in situ hybridization (FISH) in the cells of the pretreatment CSF, were included in this study. All patients were being treated intrathecally or intraventricularly with chemotherapeutic agents according to standard protocols. ${ }^{2,19}$ If three consecutive ventricular CSF samples were found to be cytologically normal, lumbar CSF was examined. Six mL of CSF, either ventricular or lumbar, was obtained before every consecutive bolus injection into the subarachnoid space and was used for the cytologic examination of Giemsa-stained slides and for the FISH procedure.

To study the possible influence of chemotherapy on the development of numerical chromosomal aberrations, we evaluated the CSF of three additional patients who were also being treated for LMMs but who had shown no aberration for chromosome 1 in their pretreatment CSF tests.

Each patient underwent a neurological examination before every intrathecal treatment was administered. This clinical neurologic status could be classified as improving, stable, or deteriorating.

\section{FISH Protocol}

After cytocentrifugation of the $70 \%$ ethanol-fixed CSF samples onto poly-L-lysine-coated glass slides, the preparations were proteolytically pretreated as previously described. ${ }^{9,20}$ Pepsin from porcine stomach (2,500 to 3,500 units per mg protein; Sigma Chemical Co, St. Louis, MO) was applied at a concentration of $100 \mu \mathrm{g} / \mathrm{mL}$. in $0.01 \mathrm{~N} \mathrm{HCl}$ for 20 minutes at $37^{\circ} \mathrm{C}$. After the pepsin digestion step, the slides were rinsed for 5 minutes in $0.01 \mathrm{~N} \mathrm{HCl}$ at room temperature and subsequently dehydrated in an acidified ethanol series $(70 \%, 96 \%$, and $100 \%$ ). After dehydration, the slides were fixed in $1 \%$ paraformaldehyde in phosphate-buffered saline for 5 minutes at room temperature, with five subsequent washes in phosphate-buffered saline and five washes in double-distilled water. Thereafter, the slides were dehydrated in $70 \%, 96 \%$, and $100 \%$ ethanol. In situ hybridization was essentially performed as previously described. ${ }^{9,20}$ The biotinylated, centromeric probe for chromosome 1 (1q12, pUC 1.77; Cooke and Hindley ${ }^{21}$ ) was hybridized to its target DNA in a hybridization buffer containing $60 \%$ formamide, $2 \times$ standard saline citrate $(\mathrm{SSC} ; 0.15 \mathrm{NaCl}, 15 \mathrm{mmol} / \mathrm{L} \mathrm{Na}$ citrate; $\mathrm{pH}$ 7.0), $10 \%$ dextran sulfate, $0.2 \mathrm{mg} / \mathrm{mL}$ yeast tRNA, and 0.2 $\mathrm{mg} / \mathrm{mL}$ herring sperm DNA under a coverslip and denaturated at $70^{\circ} \mathrm{C}$ for 3 minutes on a heating plate. Hybridization was performed overnight in a moist chamber at $37^{\circ} \mathrm{C}$. Posthybridization washes included $0.1 \times \mathrm{SSC}$ at $60^{\circ} \mathrm{C}$ for 5 minutes, followed by two washes in $4 \times \mathrm{SSC} / \mathrm{Tw} w e e n$ 0.05\% at room temperature for 5 minutes.

The immunocytochemical detection of the biotinylated probe was achieved with fluorescein isothiocyanate (FITC)-conjugated avidin (Vector Laboratories, Burlingame, CA) and subsequent amplification of the signal by incubation with biotinylated goat antiavidin (Vector
Laboratories) and avidin-FITC (Vector Laboratories). The nuclei were stained with propidium iodide $0.5 \mu \mathrm{g} / \mathrm{mL}$ (PI; Sigma).

\section{Slide Evaluation}

We applied the FISH evaluation criteria as described before in that (a) overlapping nuclei were excluded, (b) nuclear morphology should be preserved, (c) the nucleus should be PI-positive and exhibit a low autofluorescent background, and (d) FISH signals should be of homogeneous intensity. ${ }^{8}$

Samples were classified as disomic if all nuclei examined showed two FISH signals for chromosome 1. Cells with one signal could not be interpreted as abnormal, because we had previously found that $2 \%$ to $17 \%$ of the cells in the CSF samples of patients with nonmalignant neurologic diseases showed only one FISH signal for chromosome 1 as a result of colocalization. ${ }^{9}$ Samples were classified as aneusomic if nuclei with more than two signals were observed. This numerical aberration was established in the cytologically malignant cells of the CSF samples before therapy was started, on the basis of the aberrant number of FISH signals for chromosome 1, if at least $5 \%$ of the nuclei contained this abnormal copy number, as previously described. ${ }^{22} \mathrm{We}$ could not, however, use this cutoff level for abnormality during therapy, because of the low numbers of cells in the CSF samples as a result of this therapy. Instead, the CSF samples were analyzed independently by two blinded observers (R.J.v.O., A.H.N.H.) to assess the quality of the FISH signals by applying the criteria described above. The CSF samples were classified as abnormal if nuclei with the known numerical chromosomal aberration for chromosome 1 could be detected.

A Leica-DMRBE microscope (Leica Microskopie \& Systeme $\mathrm{GmbH}$, Wetzlar, Germany) equipped with an appropriate filter set for FITC and PI was used for microscopy.

\section{RESULTS}

A total of $76 \mathrm{CSF}$ samples (59 ventricular and 17 lumbar punctures) were obtained for routine cytologic examination and for FISH studies from seven patients known to have the following malignancies: non-Hodgkin's lymphoma (three cases), breast cancer (three cases), and a malignancy of unknown primary (one case). Table 1 provides an overview of the cytology and FISH results of all samples taken

Table 1. Comparison of Results of Routine Cytology and the FISH Procedure in 76 CSF Samples of Patients Treated for LMMs

\begin{tabular}{llr}
\hline \multicolumn{1}{c}{ Cytology Result } & \multicolumn{1}{c}{ FISH Result for Chromosome 1 } \\
\hline Malignant $(\mathrm{n}=24)$ & Aneusomic (malignant) & 22 \\
& Disomic (normal) & - \\
& Not assessable & 2 \\
Suspicious $(\mathrm{n}=13)$ & Aneusomic (malignant) & 9 \\
& Disomic (normal) & 2 \\
Normal $(\mathrm{n}=31)$ & Not assessable & 2 \\
& Aneusomic (malignant) & 18 \\
& Disomic (normal) & 8 \\
Not assessable $(\mathrm{n}=8)$ & Not assessable & 5 \\
& Aneusomic (malignant) & 5 \\
& Disomic (normal) & - \\
& Not assessable & 3 \\
\hline
\end{tabular}


together. By cytology, 24 CSF samples were classified as malignant, 13 samples as suspicious, and 31 samples as normal. Eight samples were not assessable by cytology because of the absence of cells or loss of cytomorphology. When the FISH technique was used, 54 samples were found to contain aneusomic cells, which were therefore classified as malignant. Ten samples contained no aberrant cells, whereas 12 samples could not be assessed. All the cytologically malignant samples could be classified as aneusomic by FISH, except for two preparations that were not assessable by FISH because of a heterogeneous fluorescence signal distribution. FISH thus detected chromosomal aberrations in nine cytologically suspicious samples, in 18 cytologically normal samples, and in five cytologically unassessable samples, resulting in 32 additional diagnoses of malignancy. All the 26 follow-up samples of the three patients without the chromosome 1 aneusomy in the pretreatment CSF were disomic, with the exception of two samples that showed sporadic aneusomic cells.

Table 2 lists the cytology and FISH results of the individual patients and correlates these with each patient's neurologic status. A more accurate evaluation of response to intrathecal treatment was achieved by inclusion of the FISH results in six of the seven patients, and these results correlated well with each patient's neurologic status. Only in one patient (case no. 3) was no additional information obtained by the FISH method. In patient no. 6 , treatment was discontinued because of progressive neurologic deterioration, although no malignant cells were detected by cytology. The FISH procedure detected aneusomic cells in most of these cytologically normal samples. In patient no. 7 , most of the samples were cytologically suspicious for malignancy, whereas FISH detected aneusomic cells in all of these. In four patients (cases no. 1, 2, 4, and 5), malignant cells were more frequently demonstrated by FISH than by routine cytology. In these patients, cytology performed on lumbar CSF demonstrated the presence of malignant cells despite a persistently cytologically normal ventricular CSF for five tests, whereas in four of these instances, aneusomic cells were still detected by FISH in these ventricular CSF samples.

The FISH results correlated better with the clinical neurologic status in that aneusomic cells were found more often in the CSF samples of clinically deteriorating patients than malignant cells were detected by cytologic examination (20v nine samples, respectively). Also, aneusomy was detected by FISH more frequently than malignant cells were

Table 2. Results of Cytology and FISH in Consecutive CSF Samples of Individual Patients, Combined With Patient Neurologic Statuses

\begin{tabular}{|c|c|c|c|c|c|c|c|c|c|c|c|c|c|c|c|c|c|}
\hline \multirow{2}{*}{$\begin{array}{l}\text { Patient No. and } \\
\text { Primary Tumor Type }\end{array}$} & \multirow[b]{2}{*}{ Parameter } & \multicolumn{16}{|c|}{ CSF No. } \\
\hline & & 1 & 2 & 3 & 4 & 5 & 6 & 7 & 8 & 9 & 10 & 11 & 12 & 13 & 14 & 15 & 16 \\
\hline \multirow[t]{3}{*}{ 1. Breast cancer } & Cytology* & + & + & NA & + & NA & - & - & - & \pm & + & - & - & - & - & - & - \\
\hline & FISH† & + & + & + & + & NA & - & - & - & + & + & - & + & - & + & + & NA \\
\hline & Neurolキ & impr & impr & impr & impr & impr & impr & impr & stable & stable & stable & det & det & det & det & det & det \\
\hline \multirow[t]{3}{*}{ 2. Breast cancer } & Cytology & + & + & - & NA & \pm & - & - & - & + & - & - & - & + & \pm & NA & \\
\hline & FISH & + & + & - & NA & + & + & + & NA & & + & + & NA & + & NA & + & \\
\hline & Neurol & stable & stable & stable & stable & stable & stable & stable & stable & stable & stable & stable & stable & stable & stable & stable & \\
\hline \multirow[t]{3}{*}{ 3. Breast cancer } & Cytology & + & + & + & + & + & + & \pm & + & NA & + & & & & & & \\
\hline & FISH & + & + & NA & + & + & + & - & + & + & NA & & & & & & \\
\hline & Neurol & stable & stable & stable & stable & stable & stable & det & det & det & det & & & & & & \\
\hline \multirow[t]{3}{*}{ 4. $\mathrm{NHL}$} & Cytology & + & + & + & + & + & NA & - & NA & \pm & NA & & & & & & \\
\hline & FISH & + & + & + & + & + & + & + & + & - & NA & & & & & & \\
\hline & Neurol & det & det & det & det & det & det & det & det & det & det & & & & & & \\
\hline \multirow[t]{3}{*}{ 5. $\mathrm{NHL}$} & Cytology & \pm & - & - & - & - & \pm & + & \pm & - & - & - & - & - & \pm & - & \\
\hline & FISH & + & + & + & + & + & + & NA & + & + & + & - & - & + & + & NA & \\
\hline & Neurol & stable & stable & stable & stable & stable & stable & stable & stable & stable & stable & det & det & det & det & det & \\
\hline \multirow[t]{3}{*}{ 6. NHL } & Cytology & + & + & - & - & - & - & & & & & & & & & & \\
\hline & FISH & + & + & + & NA & + & + & & & & & & & & & & \\
\hline & Neurol & det & det & det & det & det & det & & & & & & & & & & \\
\hline \multirow{3}{*}{$\begin{array}{l}\text { 7. Unknown } \\
\text { primary }\end{array}$} & Cytology & + & \pm & \pm & \pm & \pm & & & & & & & & & & & \\
\hline & FISH & + & + & + & + & + & & & & & & & & & & & \\
\hline & Neurol & stable & stable & stable & stable & stable & & & & & & & & & & & \\
\hline
\end{tabular}

Abbreviations: NA, not assessable; neurol, neurologic status; NHL, non-Hodgkin's lymphoma.

${ }^{*}$ Cytology results: + , malignant; \pm , suspicious for malignancy; - , normal CSF; NA, not assessable.

†FISH results: +, aneusomy; -, disomy (normal); NA, not assessable.

キNeurologic status: impr, improving; stable; det, deteriorating. 
found by cytology in the CSF samples during stable disease (30 v 11 samples, respectively).

\section{DISCUSSION}

A major problem in the current treatment of LMM patients is the inaccurate assessment of tumor response to treatment. Tumor response is generally assessed by sequential cytologic screening of CSF, using the detection of malignant cells as the major criterion. ${ }^{2}$ However, cytology of CSF is only moderately sensitive during treatment, because of a decrease in cell number and changes in cell morphology. As a result, the correlation between the outcome of routine cytodiagnosis and treatment response is weak.

Because the evaluation of treatment could not be improved by the application of immunocytochemical procedures or by assays for tumor markers, ${ }^{1,2}$ we analyzed the potential value of interphase cytogenetics in the evaluation of response to treatment in patients with LMMs. We assessed the chromosome 1 content in cells of sequential CSF samples obtained during treatment of seven patients known to have a numerical aberration for chromosome 1 in cells of the pretreatment CSF. Although the involvement of chromosome 1 during tumorigenesis is rather nonspecific and a result of the increased genetic instability characteristic of solid tumors, it is a good marker for aneuploidy. ${ }^{23,24}$ This has been demonstrated, for example, in breast cancer and bladder cancer. ${ }^{10,14,24}$ Furthermore, in the case of breast cancer, a gain of chromosome 1 is believed to precede invasion. ${ }^{25}$ Contrary to these solid tumor findings, a gain of copy number for chromosome 1 is less frequently observed in hematologic malignancies, although Johansson et $\mathrm{al}^{26}$ found a gain in the copy number of this chromosome in almost $20 \%$ of a series of non-Hodgkin's lymphoma patients during lymphoma progression. Furthermore, aneuploidy of chromosome 1 has not been detected in nonmalignant suspensions of different origin, so it could be used as a marker of (pre)malignancy. ${ }^{12,13,15}$ As for the cells present in CSF, we have demonstrated earlier that aneusomy was only present in CSF samples with cytologically malignant cells and not in nonmalignant CSF samples. ${ }^{9}$ In that study, we demonstrated that aneusomy for chromosome 1 could be detected in $85 \%$ of the cytologically malignant CSF samples of patients with solid tumors and, more specifically, in up to $80 \%$ of the breast cancer patients. Furthermore, we found a gain in the copy number of chromosome 1 in $50 \%$ of the CSF samples of patients with non-Hodgkin's lymphoma. Ideally, the primary tumor should be karyotyped to analyze its specific genetic aberration, which could then be used to analyze the cells present in the CSF to detect residual disease during treatment. However, this technique is timeconsuming, making this option unfeasible in a clinical setting because therapy has to be initiated as soon as possible after the diagnosis of LMMs has been made. Instead of karyotyping, the cells in the first cytologically malignant CSF sample might be screened by interphase cytogenetics with a panel of probes to find a reliable genetic marker to evaluate the response to treatment in larger numbers of patients.

Although aneusomic cells might develop infrequently during therapy (two of the 26 control samples of treated patients sporadically contained aneusomic cells), this does not interfere with the evaluation of the response to therapy in patients with a known aberration of chromosome 1 .

In all, FISH classified 54 samples as aneusomic, which were therefore regarded as malignant. In only 24 of these 54 samples could malignant cells be detected by means of routine cytology. The higher sensitivity of the FISH technique can be explained from its more objective assessment, ${ }^{8}$ because strict criteria were applied before cells were considered to be aneusomic, whereas cytology depends more on a subjective assessment of cytomorphologic features. ${ }^{27}$ There are several reasons to take the FISH results in these samples as an indication of the presence of malignancy. First of all, in all samples with cytologically normal ventricular CSF but abnormal FISH results, the presence of malignant cells was demonstrated in the lumbar CSF by cytodiagnosis. Secondly, clinical deterioration despite normal CSF cytology but in the presence of aneusomy was seen in two of the patients.

Thus the FISH results correlated better with the clinical course. Grossman et $\mathrm{al}^{28}$ stated that no correlation exists between neurologic status and CSF cytology during treatment. Others, by contrast, found a good correlation between the CSF cytology results and clinical parameters and recommended both criteria for response evaluation. ${ }^{5,29}$ Boogerd et $\mathrm{al}^{3}$ found that neurologic status after the first 6 weeks of treatment was a better predictor than the cytologic response at that time. Our results demonstrate that the correlation between cytology and the clinical course is weak, whereas the FISH results correlate better with the neurologic status and course of the disease. It was especially in cases with deteriorating neurologic status that more often abnormal CSF samples were detected by the FISH procedure than by routine cytology. In cases with stable neurologic disease, clinical status alone is a poor predictor of response to therapy. Our results demonstrate that taking the FISH results into account enables one to discriminate between stable neurologic disease due to response to therapy and apparent stabilization due to severely damaged neural tissue but without response to therapy.

Besides cytomorphologic examination, monitoring of response to treatment has been assessed by the use of 
biochemical markers. Only serial measurements of carcinoembryonic antigen in the CSF has been found to function as useful marker in monitoring the response to therapy of LMMs from solid tumors. ${ }^{6}$ Other markers, such as lactate dehydrogenase, beta-glucuronidase, and beta- 2 microglobulin, could not be recommended as response criteria during treatment. ${ }^{30}$ Also, the application of immunocytochemistry using several monoclonal antibodies to detect malignant cells in the CSF samples of patients with LMMs of solid tumors resulted in only a minor increase in diagnostic accuracy. ${ }^{31}$ However, by using an enzyme-linked immunosorbent assay, Kersten et $\mathrm{al}^{7}$ demonstrated a higher sensitivity of serial measurements of the soluble form of CD27 in the CSF of patients with LMMs of certain hematologic malignancies, compared with routine cytology.

The question remains whether the FISH results would have influenced the treatment protocol had they been taken into account. In two patients with stable neurologic disease and normal cytology of the ventricular CSF, but with an aberration detected by FISH and positive cytology of the lumbar CSF, an alternative drug would have been administered if the FISH results had guided the treatment. In another patient with stable neurologic disease and persistently suspicious cytology, FISH determined aneusomic cells in all samples, supporting the diagnosis of persistent LMMs and thus providing an extra argument for changing the drug being used. Another patient showed clinical dete- rioration even though lumbar CSF cytology results apparently normalized during therapy. There are currently no clear guidelines in such cases. Zachariah et $\mathrm{al}^{32}$ stated that other chemotherapeutic agents must be used whenever the neurologic status deteriorates despite normal cytology results. Other authors have used only CSF cytology as a response parameter ${ }^{19,33}$ because a deterioration of neurologic symptoms and signs could be the result of ongoing damage to nervous-system tissue. The FISH procedure now offers the clinician an extra argument for changing an ineffective therapy at an earlier stage in the course of treatment, as illustrated in our patient with consecutive cytologically normal CSF samples that all, however, contained aneusomic cells detected by FISH.

Furthermore, lumbar punctures could have been avoided in some patients. Because the sensitivity of CSF cytology decreases as a result of the decreasing number of cells in the course of treatment, ${ }^{4}$ a phenomenon that is especially obvious in the cytology of the ventricular $\mathrm{CSF}^{34}$ a reliable diagnosis can be made if the clearance of malignant cells from ventricular CSF during treatment is confirmed by cytologic examination of lumbar $\mathrm{CSF}^{4}$ Also, we found malignant cells by lumbar cytology five times in our series of patients, despite consecutively normal ventricular CSF cytology in all five. In four of these five, an aberration in chromosome 1 was still detectable in the ventricular CSF by the FISH technique.

\section{REFERENCES}

1. Posner JB: Neurologic Complications of Cancer. Philadelphia, PA, F.A. Davis, 1995, pp 143-171

2. Chamberlain MC: Leptomeningeal metastases, in Vecht $\mathrm{ChJ}$ (ed): Handbook of Clinical Neurology (vol 25). Amsterdam, the Netherlands, Elsevier Science BV, 1997, pp 151-165

3. Boogerd W, Hart AA, van der Sande JJ, et al: Meningeal carcinomatosis in breast cancer: Prognostic factors and influence of treatment. Cancer 67:1685-1695, 1995

4. Twijnstra A, Glass JP: Leptomeningeal metastasis from solid extracranial tumors, in Twijnstra A, Keyser A, Ongerboer de Visser BW (eds): Neuro-Oncology. Amsterdam, the Netherlands, Elsevier Science Publishers, 1993, pp 257-279

5. Shapiro WR, Posner JB, Ushio Y, et al: Treatment of meningeal neoplasms. Cancer Treat Rep 61:733-743, 1977

6. Yap BS, Yap HY, Fritsche HA, et al: CSF carcinoembryonic antigen in meningeal carcinomatosis from breast cancer. JAMA 244 : 1601-1603, 1980

7. Kersten MJ, Evers LM, Dellemijn PLI, et al: Elevation of cerebrospinal fluid soluble CD27 levels in patients with meningeal localization of lymphoid malignancies. Blood 87:1985-1989, 1996

8. Hopman AHN, Voorter CEM, Ramaekers FCS: Detection of genomic changes in cancer by in situ hybridization. Mol Biol Rep 19:31-44, 1994
9. van Oostenbrugge RJ, Hopman AH, Lenders MH, et al: Detection of malignant cells in cerebrospinal fluid using fluorescence in situ hybridization. J Neuropathol Exp Neurol 56:743-748, 1997

10. Hopman AHN, Moesker O, Smeets AWGB, et al: Numerical chromosome 1, 7, 9, and 11 aberrations in bladder cancer detected by in situ hybridization. Cancer Res 51:644-651, 1991

11. Shackney SE, Singh SG, Yakulis R, et al: Aneuploidy in breast cancer: A fluorescence in situ hybridization study. Cytometry 22:282291, 1995

12. Segers $P$, Haesen S, Castelain P, et al: Study of numerical aberrations of chromosome 1 by fluorescent in situ hybridization and DNA content by densitometric analysis on (pre)- malignant cervical lesions. Histochem J 27:24-34, 1995

13. Bulten J, Poddighe PJ, Robben JCM, et al: Interphase cytogenetic analysis of cervical intraepithelial neoplasia. Am J Pathol 152: 495-503, 1998

14. Ichikawa D, Hashimoto N, Hoshima M, et al: Analysis of numerical aberrations in specific chromosomes by fluorescent in situ hybridization as a diagnostic tool in breast cancer. Cancer 77:20642069, 1996

15. Veltman JA, Hopman AH, Bot FJ, et al: Detection of chromosomal aberrations in cytologic brush specimens from head and neck squamous cell carcinoma. Cancer 81:309-314, 1997 
16. Zhao L, Kantarjian HM, Van Oort J, et al: Detection of residual proliferating leukemic cells by fluorescence in situ hybridization in CML patients in complete remission after interferon treatment. Leukemia 7:168-171, 1993

17. Arkesteijn GJA, Erpelinck SLA, Martens ACM, et al: The use of FISH with chromosome-specific repetitive DNA probes for the follow-up of leukemia patients. Cancer Genet Cytogenet 88:69-75, 1996

18. Wheeless LL, Reeder JE, Han R, et al: Bladder irrigation specimens assayed by fluorescence in situ hybridization to interphase nuclei. Cytometry 17:319-326, 1994

19. Ongerboer de Visser BW, Somers R, Nooyen WH, et al: Intraventricular methotrexate therapy of leptomeningeal metastasis from breast cancer. Neurology 33:1565-1572, 1983

20. Hopman AHN, Poddighe $\mathrm{P}$, Moesker $\mathrm{O}$, et al: Interphase cytogenetics: An approach to the detection of genetic aberrations in tumours, in Herrington CS, McGee JO'D (eds): Diagnostic Molecular Pathology: A Practical Approach (vol 1). Oxford, England, IRL Press, 1992, pp 141-161

21. Cooke HJ, Hindley J: Cloning of human satellite III DNA: Different components are on different chromosomes. Nucleic Acids Res 6:3177-3197, 1979

22. Van Oostenbrugge RJ, Hopman AHN, Arends JW, et al: The value of interphase cytogenetics in cytology for the diagnosis of leptomeningeal metastases. Neurology 51:906-908, 1998

23. Shackney SE, Shankey TV: Common patterns of genetic evolution in human solid tumors. Cytometry 29:1-27, 1997

24. van Dekken H, Rosenberg C, Krijtenburg PJ, et al: Interphase cytogenetics and comparative genomic hybridization of human epithelial cancers and precursor lesions. Histochem Cell Biol 108:419-430, 1997
25. Harrison M, Magee HM, O’Loughlin J, et al: Chromosome 1 aneusomy, identified by interphase cytogenetics, in mammographically detected ductal carcinoma in situ of the breast. J Pathol 175:303-309, 1995

26. Johansson B, Mertens F, Mitelman F: Cytogenetic evolution patterns in non-Hodgkin's lymphoma. Blood 86:3905-3914, 1995

27. Andrews JM, Schumann GB: Neurocytopathology. Baltimore, MD, Williams \& Wilkins, 1992, pp 52-64

28. Grossman SA, Finkelstein DM, Ruckdeschel JC, et al: Randomized prospective comparison of intraventricular methotrexate and thiotepa in patients with previously untreated neoplastic meningitis. J Clin Oncol 11:561-569, 1993

29. Wasserstrom WR, Glass JP, Posner JB: Diagnosis and treatment of leptomeningeal metastases from solid tumors: Experience with 90 patients. Cancer 49:759-772, 1982

30. van Zanten AP, Twijnstra A, Ongerboer de Visser BW, et al: Cerebrospinal fluid tumour markers in patients treated for meningeal malignancy. J Neurol Neurosurg Psychiatry 54:119-123, 1991

31. Boogerd W, Vroom ThM, van Heerde P, et al: CSF cytology versus immunocytochemistry in meningeal carcinomatosis. J Neurol Neurosurg Psychiatry 51:142-145, 1988

32. Zachariah B, Zachariah SB, Varghese R, et al: Carcinomatous meningitis: Clinical manifestations and management. Int J Clin Pharmacol Ther 33:7-12, 1995

33. Siegal T, Lossos A, Pfeffer MR: Leptomeningeal metastases: Analysis of 31 patients with sustained off-therapy response following combined-modality therapy. Neurology 44:1463-1469, 1994

34. Rogers LR, Duchesneau PM, Nunez C, et al: Comparison of cisternal and lumbar CSF examination in leptomeningeal metastases. Neurology 42:1239-1241, 1992 